\title{
Lost in Translation: An Exploration of Political Writing during Anti-imperial Struggles in Burma in the Late 1930s, with a Particular Emphasis on Works of Translation
}

\author{
Joanne Money \\ University of Sunderland, UK \\ *Corresponding Author: Joannedunne21@hotmail.com
}

Copyright (C 2014 Horizon Research Publishing All rights reserved.

\begin{abstract}
During the late 1930s an evolution of Burmese writing took place, which was marked by a conscious movement to introduce new ideas in literature that would motivate the Burmese people to rise up against the British in a bid for independence. Works from western authors were adapted to reflect the growth of national feeling in Burma. The aim of this paper will be to question how far and to what extent can a work of translation become a political tool. Further, what is translation anyway? Translations are never written in a vacuum nor are they received in one, therefore can the translator position himself within the actual text produced, so that the translation will be so close to the cultural centre of the target audience that the translation might become the original? Using a form of discourse analysis this paper will examine the work of Thein Pe in particular and the role of the Nagani Book club to question how far translations can indeed become political and to what extent they were successful as a tool of nationalism. The difference between a work of translation and an adaptation is slight. In his foreword to his 1940 novel 'oil' Thein Pe describes himslef as a translator, and his novel as a work of adaptation.I would argue that the cultural dichotomy between two opposing rationales (East and West) was at the crux of the political/literary debate during this period. This can be examined on several different levels: Eastern vs Western perspective, or capitalist vs socialist ideology, nevertheless the question remains: can a literary translation be termed political and if so to what extent.
\end{abstract}

Keywords Translation, Politics, Nationalism, Literature, Burma

\section{Introduction}

The 1930s were decisive years for Burmese politics. The 1920s had marked a profound change in the way that the Burmese viewed colonialism, and there was a noticeable shift in the way anti-imperialism and nationalism had progressed; political parties, student politicians, and the anti-Indian and Chinese riots of 1929 had shown the British that sections of the nationalist movements were deadly serious in their convictions against the unfairness of colonialism.

During the late 20s and 30s many nationalists (many of whom were also writers), saw literature as an opportunity to educate the people, and promote the ideology of nationalism. The Nagani (Red Dragon Left Wing) Book Club was founded in 1937 in Rangoon, and was based on the model of Victor Gollancz' Left Book Club of London. Nagani became a political platform from which the literature of politics could take place. Most of the founding members were closely linked to the Thakin (Thakin - meaning master and effectively saying to the British "we are masters of our nation") nationalist movement, and the club itself was dedicated to serve the purpose of establishing a cultural and political revolution in Burma that would benefit the Burmese people, and help re-create a sense of purpose and quest for freedom. During this time many nations were looking towards 'the left' for a political ideology that would oppose colonialism.

The relationship between literature, education and what would evolve into politics had begun in 1924, when the British civil servant (and staunch supporter of all things Burmese), J.S. Furnivall founded 'The World of Books' magazine, and in 1928 'The Burmese Education Extension Association', and Burma Book Club. All served the purpose of bringing the young generation of Burmese students in contact with the diverse amount of international literature and stimulating discussion on current affairs. However, Furnivall's magazine was bilingual, and stressed the importance of understanding English, and this was a contentious issue with many nationalists who wanted to 
encourage the Burmese language. Nevertheless an ability to read and understand English was acknowledged as a necessary evil, and it was through Furnivall's Book Club that English language Marxist books first became readily available to Burmese nationalists. Translated works of manuscripts of British writers like John Strachey and the theoretician of the British Communist Party R. Palme Dutt, and later books recommended by Pandit Nehru in his Impressions of Soviet Russia became key texts that the Marxist nationalists began to use in an attempt to find an ideology that would challenge imperialism.

The left wing Thakins accepted the validity of Marxist revolutionary and international political analysis, but it was only in 1937, when the Nagani Book Club and publishing house was founded by Thakin $\mathrm{Nu}$, and other prominent nationalist politicians that writings in Burmese became readily available. In analytical terms, the nationalists of Nagani placed Burmese politics and the struggle for independence within the context of world politics. Burma's subjugation was seen as part of a worldwide system of capitalism and imperialism, and the Burmese nationalist movement was described, not as an isolated phenomenon, but as part of a global struggle of the oppressed colonies and independent capitalist states against their exploiters. Nagani began to publish from a wide range of sources, but the main objective was to be free of British rule and in order to do this they would have to revolutionise the minds of the people. In 1939 two prominent politicians, U Nu and Hle Pe produced a double volume of texts entitled Political Map and Dictionary of Political Terms from around the World. The two volumes were taken together in an aim to instruct the people of the political / historical situation around the globe. This was a form of geo-politics - the forerunner of post-colonial globalisation theory - a study that analysis geography, social science and history, with reference to spatial politics and patterns of reference at various scales, ranging from local level of the state through to international. Thus the theory examines the political, economic and strategic significance where it is defined in terms of location, function and relationships of places and resources. Both volumes gave particular emphasis to countries that had been subjected to suppression, in particular the situation in Ireland, and the nationalist work of the political poet Patrick Pearce, who was part of the nationalist 1916 Easter Rising against British occupation, and the Burmese would often refer to themselves as "The Irish of the East". The Philippine nationalist writer Jose Rizal also featured very heavily within the literature. Similarly, Rizal is referred to as "the father of Philippine independence". Thus, by using actual examples of revolutionaries and translating their reasoning and philosophies, and by educating the Burmese people about the wider world, with a strong focus of suppressed countries, a united Burmese identity might be forged against imperialism. Revolutionary ideas and experiences of other countries were thought to be the way forward. Prominent politician Ba Thaung, 1939 echoes the words of Nietzsche:
The goal is not the creation of a national unit built upon military power of wealth, but the production of an elite from which genius will arise who will show mankind new values (Ba Thaung, 1939).

Nietzsche's 1822 The Gay Science was itself a variation / collection of thoughts and feelings, but based on thirteenth century European poetry. Nietzsche based much of his work on moral psychology and the origin of values. He experiments with the notion of power, but does not advance into any systematic theory, but instead focus's on the doctrine of eternal re-occurrence and a proper attitude towards human suffering and human achievement. Therefore, his ideology would have fitted into the value system of Buddhist based nationalism, and furthermore advocates just how well versed the Nagani translators were in western philosophy.

Nagani wanted to use positive role models, not only for their achievements, but also as an ideology for their tragic fate, as seen with Rizal and Pearce. Rizal in particular was perfect because he was also a scholar and was willing to sacrifice his life for his people and country. He thus embodied what Nagani was trying to teach the people in the field of literary and intellectual education, as both a fighter for justice and that he personified a commitment to his aims and ideals. From 1938-1940 the list of biographies published by Nagani support the evidence ${ }^{1}$ and the list forms a pattern of widening concentric circles starting in Asian countries close to the current revolutionary situation in Burma and extending in space and time to Europe and America and earlier historical periods. Burma itself had no history or knowledge of revolution, and ideas had to be imported and transferred (and literally translated) into the Burmese context. In other words, "A Burmese Revolution" had to be conceptualised and modelled and the books were used as tools for this undertaking.

As the Nagani became increasingly political British intelligence became aware of its purpose, and in December 1937 records note "It's aim is to train leaders to fight against imperialism and it proposes to issue books in furtherance of this objective" ${ }^{2}$. The British were suspect of any organisation, which might threaten their rule, but at this period in time they were less concerned with left-wing ideology as any ideology that might give threaten to their authority. Indeed, the Burmese nationalists themselves were searching for 'any' philosophy which could challenge imperialism, and the prominent perspective during the 30 s appeared to be left-wing (Marxist/socialist/communist), but this would become something that threaten international political complexities and uncertainties that surrounded Asian nationalism during the 30's and 40's and beyond.

\section{Translation or Adaption?}

1 Jose Rizal, May 1938; Atakirk, Feb 1939; Lenin, April 1939; Asoka, Aug 1939; De Valera, Sept 1939; Lincoln, Nov 1939; Napoleon, October 1940

${ }^{2}$ See Indian Office Collections M/5/54:22Dec 37 
With outbreak of war in Europe, the nationalist movement gained a new imputus in Burma. The Thakins joined forces with Ba Maw's Sinyetha party to form the "Freedom Bloc", and to press for independence. Both $\mathrm{U} \mathrm{Nu}$ and Thein Pe were a founding members of the Freedom Bloc, and both were prolific opinionated writers. By looking at their work, juxtaposed with the political situation at the time, how far can we judge the work to be political, and indeed successful as tools of nationalist, anti-imperial propaganda?

The most distinctive feature of Thein Pe's stories are the political content, and his political philospohy is reflected in them. In the introduction to his 1938 story A Song to Make One Weep he states: "I had always wanted to be a novelist, but while the political situation in Burma was not to my liking, I felt I had to take an active part in righting it". His solution was to try and combine the two careers of literature and politics, and to use his writing to propogate his views. His art reflects the view that literature must make a conscious effort to reflect life, as oppossed to the philosophy "art for art's sake". Further, another importamt feature of the stories is the sense of actuality which they convey. Thein Pe used his own experiences mixed with those of his generation, thus making the stories semi-autobiographical, in addition the stories are often based on actual events, and the main characters are intended to be representative of the period in which they are set. However, within this premise there lies a dilema: Thein Pe's writing was often an adaptation / translation of another story. Indeed one of the most relevent is his 1938 story "Oil", which was written after his return from India, and is an adaption of Upton Sinclaire's 1927 novel of the same name. the East vs West situation is a prominant feature, but how Thein Pe constructs and adapts his narrative to fit the Burmese culture is particualrly significant. Furthermore, in his foreword to the book he calls himself a translator, but he calls the book an adaptation. Therefore, for the pupose of this analysis the book can be seen as an adaptation rather than a direct translation. The expression 'translation' is quite a broad definition in itself, and several theorists began to discuss this at some length during the $70 \mathrm{~s}, 80 \mathrm{~s}$, and more so the $90 \mathrm{~s}$, as Susan Bassnet has examined 'what is translation anyway?' and the actual techniques within translation change with time. Derrida, suggests that 'translation itself becomes the original', for example ancient 'translators' translated in terms of their own culture, and some translators deliberately positioned themselves within the text they produced, so that the translation would be so close to the cultural centre of the target audience that the translation would become the 'original'. This was more so if the audience had no access to the original. Therefore, to term anything as translation; adaption; rewriting; version etc is difficult to actually pin down.

Sinclaire's novel centres on the lives of oil field workers in Southern Calafornia and their struggle against the rich, bigamists who exploit the workers of small town in America. Thein Pe's narrative too describes the life of oil field workers and the beginnings of their opposition to capitalism. Pe's story concerns oil field worker, Ko Lu Dok, and his reaction to a frustrating prediciment: because of lack of money to buy oil, even though he lives in the midst of plenty in a village on an oil field, he cannot provide a light so that his son learn 'proper' i.e Buddhist prayers. His answer to this is to steal some oil, and he rationlises this by claiming that he is only taking back what is rightfully his as a Burman. However, when he finds out that a fellow worker has been fined because of the missing oil, he steels his daughter's ring to pay the fine, and this in turn causes his son and daughter to argue. His realisation that the oil has caused dissention for his own family, trouble for his friend, and degration for himself leads him to pour the oil back into the ground with a curse. The story works on two levels to juxtapose the literary with the political and nationalist dogma: The greed of the capitalist imperialist regime that propagates personal greed, and thus undermines traditional Buddhist values, and serves as a critique of the type of social systems that imperialism has brought with it.

Thein Pe's personal centre of culture at the given historical period thus conveys a sense of actuality that the reader would be able to comprehend. At the time that it was written there was much industrial unrest within the oil-fields in Burma, which was being encouraged by the Thakin nationalists. However, BOC (Burma Oil Company - British owned) regually had strikes: from 1920-30 strikes took place on a yearly basis, and from 1931-36 there was an average of four strikes per year. Therefore, his choice of translation would appear to be aprticularly apt. Further, using Lefevere theory of translation ${ }^{3}$, in which he gives four reasons why a writer would choose to translate rather than create an original, these are: A way of giving direct information; a means of belonging to the cultural capital; for pure entertainment; an attempt to persuade the reader to adopt a particular course of action. Thein Pe's adaptation would therefore fit neatly into the latter rationale. The adaptation presents no alteration in the theme or progress of the original story. Characters names have been changed, as have concepts for example in the original, when offering guests drinks: 'Would you care for a rum or brandy?' In the adaptation: 'Would you care for a coffee, tea or cocoa?' Burman's do not drink alcohol at home, so this would seem unrealistic to the audience. Further, Thein Pe had to delete certain phrases, and western niceties such as drinking to 'Your good health'. As Susan Bassnet concludes: 'translations are never written in a vacuum, nor are they received in one and as such the way and reason a translation is written may well depend upon the audience for which it is intended' (Bassnet, 1988, p99). Perhaps this would seem like a clear observation, and that certain things must be changed to make sense to the target audience, but Thein Pe's novel also suggests that society itself is complex and that democracy and human rights are not straightforward.

\footnotetext{
${ }^{3}$ Lefevere and Bassnet, 1997, looked at translation theory as any text produced on the basis of another has the intention of adapting that other text to a certain ideology or to certain poetics and usually both
} 
Similarly, Sinclair's novel is set in Southern California in the early part of the $20^{\text {th }}$ century. It is a social and political satire concerning rich oil tycoon, James Arnold, and his relationship with his socialist thinking son, set with the evangelical movement in the background. The oil tycoons' 'rip' the oil from the earth, and the contagious greed drives other men to do the same in the name of capitalism, whilst building a ruthless empire on the other men's' blood (the 2007 film There Will be Blood is based on the novel). Oil closes with the son realising that "an evil power roams the earth, giving nations to destruction by visions of unearned wealth" (Sinclaire, 1927, pp67).

Both writers had a strong critique of capitalism, which favoured a socialist approach to politics and nationalism, and Thein Pe's communist leanings were well documented, but as the ultimate aim of the nationalist Thakin party was freedom from British rule, they became increasingly aware that in order to do this it would be necessary to gain access to an external source of supply for arms and ammunition. The British government's growing fears of the strong appeal of Marxism led them to arrest members of the Thakin party, so many that Insein jail in Rangoon began to be known as a "school for communism". Papers seized from jailed Thakin's indicated that they were studying Nagani translations of the Russian Revolution, and other communist renditions. However, the arrest of so many left-wing nationalists had far-reaching and unforeseen consequences. Party members who remained outside detention entered into conspiratorial manoeuvres with the fascist Japanese, a move that would influence the future of Asian politics for decades to follow. Japanese troops were welcomed as heroes against the occupying colonialists in many parts of Southeast Asia, as the rising power of the fellow Asian nation proved a compelling incentive regardless of the Japanese fascist ideology. The Burmese nationalists did indeed side with the Japanese, and British forces were defeated. However, the promised independence from Japan never materialised. The consequences of this were dire, and splits between factions of the Burmese nationalists were the cause of civil unrest for the decades to follow.

In summery, how far then can we conclude that the Burmese translations were successful as political tools against colonialism? I would argue that the Burmese political authors were well versed with the political climate at the time, and naturally anti-imperialistic views; socialist based, were at the forefront of any ideology that the Burmese nationalists were seeking. Without a doubt Thein Pe's Oil was a strategic move to promote this philosophy. A clue to his conviction lies within the preface to his version:

The Burmese word for 'oil' is yenan, smelly water. There is no water in oil. It is a combustible liquid and its qualities are a far cry from ordinary water. Although it is simply called 'oil', it is different from other oils as sesame oil, coconut oil, groundnut oil, mustard oil, etc. You can't extract expensive materials from these ordinary oils, but from petroleum oil, you can extract good quality petrol, low quality petrol, kerosene oil, candle wax, tar, etc. There is a considerable output of oil in Burma but before Burma deteriorated, it was not deemed valuable. What the Burmese kings esteemed were gold and silver mines, sapphire and copper mines, and not the oilfields. The petroleum sellers were looked down upon and can be surmised from such derogatory proverbs as 'The castor oil plant reigns in a forest where there are no rich or valuable plants', 'The petroleum seller is waving his head band' (i.e. he is showing off his lowly status when he has no reason at all to do so). In bygone eras, petroleum was used only in lighting torches, and in coating surfaces such as boats, carts and houses to prevent from decay by termites. When Burma disintegrated, there were also many changes in the world. You can call those times as the oil era. You can even call the First World War as the Oil War. Nowadays in the developed and cultured world, no one is immune from the usage of oil. You light candles at your altar at night, you ride on cars and crafts that are moved by oil, those dreadful aeroplanes that are dropping bombs are driven by oil. Oh Oil! You have been beneficial in our daily lives but you have also been a cause in our destruction. If you blame oil for our inconveniences, how do you think the oil will answer back? "Friends! I am just a lifeless material. Because I like to be alone and do not want to have relations with you humans, I stay hidden under layers and strata of earth and rocks. Only when you humankind comes with your big machineries to extract me from under and use me in your nefarious acts, then these difficulties arise. Why blame me from all the consequences?" If the oil wraps a pickled laphet tea and hires a lawyer (an old Burmese custom on hiring a lawyer), how shall we answer him back in the court of law? Oh Oil! You are meant to be good. Humans have tarnished and destroyed your reputation. Oh! How pitiable!_(Thein Pe, 1939).

In conclusion, the ideology that Nagani sought to promote ultimately failed, but the resulting literature proved to be a sustaining force. And although the decades following independence were filled with civil and national unrest, the literature produced during the years of Nagani has survived as a source of inspiration for future generations of Burmese who now look at as a driving force in an ever-challenging world.

\section{REFERENCES}

[1] Aung Htin, 1945, “Thein Hpei, Rangoon

[2] Aung San, 1946, “Burma’s Challenge” Tatheta Sapei

[3] Bagley, J, 1969, “ Breakthrough in Burma”, New Jersey, prentice Hall

[4] Ba Maw, 1968 “ Breakthrough in Burma”, Yale University Press.

[5] Cady, J, 1958, "History of Modern Burma" Cornell 


\section{University Press}

[6] Derrida, J, ,1978, "Writing and Difference

[7] Do Bama, 1976, “Asia-yon Preperation Committee” Rangoon,

[8] Lefevere, A and Bassnet, S, 1997, "Constructuring Cultures", London
[9] Mountabatton, 1951, "Reports to Allied Commanders South East Asia” London, His Majesty's Office

[10] Nu, U, 1975, "Saturdays Child" Nu, U, 1946, "Five Seasons in Burma" Rangoon

[11] Thein pe, 1956, "Critique of Imperialism” Rangoon

[12] Tun Pe, 1946, "Sun over Burma”, Rangoon, Rangani Press 